\title{
The McDonaldization of Academic Libraries and the Values of Transformational Change
}

\section{Karen P. Nicholson}

In his article "The McDonaldization of Academic Libraries?" Brian Quinn explores to what extent and to what effect academic libraries have become "McDonaldized," according to the concept developed by sociologist George Ritzer. ${ }^{1}$ Quinn identifies a number of ways in which the four dimensions of McDonaldization-efficiency, calculability, predictability, and control (typically realized through the substitution of technology for human labor) - are evident in academic libraries. Tiered reference service, self-check machines, and self-guided tours all represent ways in which libraries have sought to become more efficient. "Just-in-time" approaches to collection development-including a greater reliance on interlibrary loan and document delivery services, part of a larger trend toward access over ownership - and standardized approaches to information literacy instruction also provide greater efficiencies. Calculability is represented in the focus on quantity, such as inputs (like financial resources, number of staff, gate counts, number of volumes) and outputs (for instance, circulation stats, online transactions), as a surrogate for quality. McDonaldization is also apparent in the growing predictability of academic libraries' collections resulting from the use of approval plans and journal aggregator databases. Likewise, Quinn suggests, most libraries offer the same suite of core services. Finally, in addition to their hierarchical structure and reliance on rules and regulations-typical of bureaucratic systems, and in itself a form of social control-the increasing use of technology in libraries serves as a mechanism of rationalization and control.

Although Quinn concedes that "there are obvious advantages in maintaining a wellorganized and efficient work environment," ultimately, he sees the "bureaucratic, McDonaldized environment" characteristic of academic libraries as a form of irrationality:

It is difficult to accomplish much that is innovative. Boldness, experimentation, and organizational responsiveness all suffer as a result. McDonaldized libraries are slow to respond, simplistic, and short-sighted because they are unable to engage the heads and hearts of their employees and are out of touch with the real needs of their users. ${ }^{2}$

Karen P. Nicholson is Manager, Information Literacy, at the University of Guelph, a PhD student at the University of Western Ontario, and a faculty member with the ACRL's Information Literacy Immersion programs; e-mail: kanichol@uoguelph.ca. The author would like to thank Wendy Holliday, Dr. Pamela J. McKenzie, Courtney Waugh, and the reviewers for their insightful comments on an earlier version of this essay. (C) 2015 Karen P. Nicholson, Attribution-NonCommercial (http://creativecommons.org/licenses/ by-nc/3.0/) CC BY-NC. 
Noting that many rationalized private sector companies have come to realize that their survival depends on "imaginative responses to rapid change," Quinn counsels libraries to implement corporate creativity practices-such as humor rooms, joy clubs, and skunk works - to counter the "dehumanizing and stultifying" environment of the McDonaldized library and provide a better experience for staff and users alike. ${ }^{3}$ Iconoclastic corporate cultures that promote irreverence, creativity, idiosyncrasy, and individualism are suggested as models to follow. ${ }^{4}$

In many ways, Quinn's article is highly representative of its time. The literature of the period is replete with calls for academic libraries to respond to "unprecedented," "radical," and "revolutionary" change by introducing corporate business models and practices. ${ }^{5}$ Faced with aggressive competition from bookstores, search engines, and vendors, libraries are urged to adopt client-focused approaches whereby customer preferences serve as the primary indicators of resource and service quality. ${ }^{6}$ Organizational structures need to be flattened, and administrators are obliged to take on the roles of leader, coach, and facilitator. ${ }^{7}$ Libraries must pursue "strategic thinking and action, fiscal agility, and creative approaches to the development of collections and services and to the expansion of markets" to compete in the "information marketplace" or face extinction. ${ }^{8}$

Several library and information science (LIS) researchers demonstrate, however, that, contrary to their self-proclaimed "radical" outlook, calls for libraries to change according to corporate values and models are neither unprecedented nor revolutionary. ${ }^{9}$ In a 1998 article, Mark Day argues that the discourse of transformational change in LIS literature-characterized by pleas for visionary leadership and organizational reengineering as mechanisms to assert "control over culture," and futuristic scenarios and vision statements - represents a highly predictable response to post-industrialization by modern institutions such as libraries. ${ }^{10}$

The theory and practice of management in libraries has always borrowed heavily from the dominant managerial culture.... As with everything else today, that process has speeded up, and academic library administrators are adopting the latest organizational fashions almost as quickly as their corporate counterparts. Along with other managers and organizational theorists, they also seem to have accepted as valid the core argument of the normative control paradigm... that building a strong non-bureaucratic organizational culture will enhance competitiveness, performance, and productivity as well as improve the quality of working life. ${ }^{11}$

In their 1996 book, James Gee, Glynda Hull, and Colin Lankshear explore postFordist "fast capitalism" and its impact on "the new work order."12 Fast capitalism is fuelled by globalization, hypercompetition, high tech, and "the demands and desires of increasingly sophisticated consumers." ${ }^{13}$ It reflects a paradigmatic shift from mass production to mass customization, represented by flexibility, process innovation, short product development and life cycles, and the creation and manipulation of niche markets. ${ }^{14}$ (It is important to note that, although Ritzer presents McDonald's as an examplar of Fordism, the chain moved away from standardized mass production toward mass customization as early as the late 1970s in the United States. ${ }^{15}$ ) Fundamentally, fast capitalism is about privatization and market competition in the public and private realms.

The new capitalism... advocates that, by and large, everything-business, social processes, private lives-ought to be unregulated except by the forces of competition ('markets') defined around quality as determined by 'customers'... Customization is, in the realm of design and production, a form of privatization. 
Privatization throws all of us - and is meant to- on our own resources... demanding that we take responsibility for our own lives, which themselves are seen now as... businesses ('competing in various markets'). ${ }^{16}$

A key objective of the new capitalism is creating new kinds of workers-highly flexible, empowered "portfolios" of skills and experiences ready to "throw themselves heart and soul into the work of the company in risky times." 17 To accomplish this, fast capitalist companies (like the ones Quinn names) create an "indoctrinating" culture through the use of core values, vision statements, and futurist leaders. (The American Library Association's work in defining and promoting "core values" and developing leaders through programs such as Emerging Leaders, a self-propagating initiative that ultimately serves the needs of the ALA itself by "put[ing] participants on the fast track to ALA committee volunteerism," exemplifies the influence of the new capitalism within the profession of librarianship..$^{18}$ ) Sociotechnical practices - "the design of technology and social relations within the workplace to facilitate productivity and commitment" - are used as a form of control. ${ }^{19}$ Workplaces have always been sites of enculturation; but, under the new capitalism, worker empowerment, participation in corporate culture, and the inculcation of corporate values have become a business strategy, a new soft-touch hegemony. ${ }^{20}$ So, whereas it may initially appear that "new alternative models of organization rely less on rationalization" and more on "fostering creativity and intuition among employees to solve problems," as Quinn suggests, in reality, they continue to use rationalization as a form of control. ${ }^{21}$ They are still McDonaldized, to some degree at least.

In my view, the McDonaldization of academic libraries reflects the growing influence of corporate aims and values (in other words, competition, profitability, risk, value for money, entrepreneurship) in the public sector under the neoliberal philosophy of New Public Management (NPM). ${ }^{22}$ Michèle Charbonneau describes NPM as an umbrella term for an array of practices and approaches that, to varying degrees, seek to increase effectiveness and efficiency, introduce flexibility into organizational structures through downsizing and decentralization, develop innovation and entrepreneurialism, and accord users a greater role in decision making. ${ }^{23}$ In the neoliberal "McUniversity," economic exchange becomes the defining relationship between students, staff, and the institution. ${ }^{24}$ Demands for a skilled workforce to support the global knowledge economy have resulted in the massification of higher education (" $X$ billion degrees sold worldwide") and a curricular shift toward vocationalism. $\cdot{ }^{25}$ Students are perceived as clients to whom universities are marketed as brands, and degree credentials are exchanged as commodities on the labor market. Higher education increasingly relies on a flexible, cost-efficient workforce of poorly paid adjunct faculty without job security, pensions, or benefits; Florida's newest public university, which opened in 2014 with "a no-tenure model" for its faculty (and a library without physical books), serves as a case in point. ${ }^{26}$ Academics have become entrepreneurs who must compete for jobs, students (who provide the bulk of core funding through tuition fees), and research grants. ${ }^{27}$ The number of for-profit universities is on the rise, and higher education, in partnership with the private sector, continues to pursue the "expansive markets" of distance learning and e-commerce, as evidenced by the ubiquity of learning management systems and recent joint forays into MOOCs. ${ }^{28}$

Today, the commodification of academic libraries continues apace, and the trends Quinn identifies persist. Indeed, Quinn's critique largely foreshadows the current state of academic libraries, the preoccupation with accountability and return on investment, best represented in the ACRL's Value of Academic Libraries initiative, in particular. ${ }^{29}$ The ongoing narrative in our libraries continues to be "all about production and consump- 
tion"; $; 0$ ironically, many libraries now feature chain coffee shops such as Starbucks, further blurring the lines between the fast food industry and the library. ${ }^{31}$ In the current climate of accountability and austerity, libraries have become veritably "obsess[ed] with quantitative assessment, student satisfaction, outcomes, and consumerist attitudes towards learning." 32 Many have embraced learning analytics as a means of assessing and predicting the impact of the library on student success. Libraries provide "just-in-time" opportunities for online and distance learning through the use of pathfinders, guides, and tutorials. Information literacy and other forms of instruction, such as "how to" videos, are increasingly pared down into bite-sized, easy-to-digest content chunks. ${ }^{33} \mathrm{~A}$ growing array of standards and guidelines identify best practice approaches, outcomes, and performance indicators, making libraries increasingly predictable. ${ }^{34}$ Approaches to information literacy instruction in North American academic libraries have become normalized as a result of the widespread adoption of the ACRL's Information Literacy Competency Standards, with their checklist approach to skill development. ${ }^{35}$ According to Maura Seale, this approach promotes "an uncritical consumption of information in lieu of any sort of systemic critique." ${ }^{36}$ Patron-driven acquisition represents both a "just in time" and a customer-oriented approach toward collection development. Strategies to increase "organizational flexibility and agility," such as flattened organizational structures, the outsourcing of cataloguing and library technology support, and a reliance on temporary appointments, have become commonplace. ${ }^{37}$

I contend that there are several issues with the McDonaldization of academic libraries and the concomitant discourse of transformational change (and here I include notions of market competition, entrepreneurship, consumerism/commodification, accountability, and the "exchange value" of education and information). First, transformational discourse in academic libraries is based on the flawed and reductive binary model"innovate or die" - at the heart of rational choice theory..$^{38}$ In his critique of rational choice theory, consumerism, and commodification in academic libraries, John M. Budd asks us to consider whether every encounter with a student or faculty member represents a mere "transaction," and if information is only a commodity. ${ }^{39}$ In the same vein, Barbara Fister denounces the narrow view that only radical change "counts." 40

Second, not only is this rhetoric reductive, but also, and more important, it changes what libraries are about. ${ }^{41}$ To understand this point, it is perhaps useful to go back to Ritzer's original concept of McDonaldization. Ritzer bases his work on Max Weber's theory of formal rationality, according to which "the search by people for optimum means to a given end is shaped by rules, regulations, and larger social structures." ${ }^{42}$ For Weber, the paradigmatic example of rationality is the bureaucracy. When Ritzer substitutes the fast food restaurant for the bureaucracy as the model of Western rationality, he does more than coin a contemporary catchphrase for Weber's turn-ofthe-century theory: he invokes a larger postmodern cultural narrative of production/ consumption in post-industrial, late capitalist Western society.$^{43}$ In the McDonaldization paradigm, the means (efficiency, calculability, predictability, and control) remain the same, but exchange value becomes the end. When applied to the public sector, and to higher education in particular, this has important consequences: it enacts a shift from a "bureaucratic-professional" model of accountability toward a "consumer-managerial" model, "replacing norms and values derived from assumptions about the 'common good' or "public interest"' with corporate managerialism and educational instrumentalism. ${ }^{44}$ Education no longer represents a public good; it becomes a market like any other, a process John Buschman refers to as the "dismantling of the public sphere." 45

Similarly, perceiving students and faculty as "clients" or "customers" causes "a substantial shift in the economy of the library" by introducing an economic model based on the exchange value of libraries and their services. ${ }^{46}$ Using Henri Lefebvre's 
framework of how humans interact with space, James K. Elmborg argues that, when we market library space as a product, it ceases to be an "absolute space" endowed with cultural significance, to become instead an "abstract space," emptied of intrinsic meaning and given over to commercial use and generic identity, "like mini-marts, Wal-marts, McDonalds, and malls." ${ }^{47}$ As Buschman so aptly explains,

Aping business rhetoric and models doesn't save libraries, it transforms them into something else. We're a profession and an institution in crisis because we have a structural contradiction between our purposes and practices as they've historically evolved and our adaptation to the current environment. ${ }^{48}$

Critics from a broad range of disciplines have made cogent, compelling arguments against the corporatization of higher education for many years now. ${ }^{49}$ Quinn himself highlights several of these in his article. Yet, as a profession, librarians have largely embraced - or at least unquestioningly accepted - change rhetoric and corporate models. Why is this? Ron Barnett, Robin Usher, and Richard Edwards use Lyotard's concept of "performativity"' to demonstrate that, under neoliberalism, the market becomes a technology for effecting control and enhancing performance in the public sector. ${ }^{50}$ Indeed, Ritzer selects McDonald's as his paradigmatic, contemporary model of Western rationalization over any other because "it is the symbol of the rationalization of America and its coveted market economy." ${ }^{51}$ Ngure wa Mwachofi points out that, because language is performative, McDonaldization is not an "essence" that is revealed to us; it is an ideological frame that we help to create and reproduce, one that enables certain possibilities while masking others.

The more a frame... becomes part of our culture, the more it escapes scrutiny; also, the less "visible" it becomes. In other words, paradoxically, it becomes more absent as it becomes more present. And ironically, the less visible it becomes, the more power it gains because it escapes our scrutiny. ${ }^{52}$

The discourse of transformational change, grounded in an uncritical adoption of neoliberal philosophy and corporate practices, has become the dominant ideology according to which we in academic libraries conceptualize our work, frame our "challenges," and identify their "solutions." But ideological communication is not neutral: it defines the context, limits, and possibilities of our (discursive) practice. "It asserts the truth and good of some particular idea, policy or vision for the future, [and] attempts to equate its value with the natural end that is purported to follow." 53 The narrative of change has not only become the norm in our libraries, it has become normative. ${ }^{54}$ According to David Harvey, manufacturing crises to justify the implementation of desired reforms is a key strategy in the neoliberal toolkit..$^{55}$ It is not surprising then that the incessant clamor for libraries to "innovate or die" continues today. ${ }^{56}$ In my view, when we employ transformational discourse in academic libraries, we're not "thinking outside the box" (to borrow a phrase from the corporate lexicon); we've become boxed in.

In his examination of higher education in the United States, Daniel B. Saunders notes that neoliberalism has become part of our daily fabric, informing our basic ideas and fundamental assumptions. ${ }^{57}$ Despite this, the average citizen remains largely unaware of it (although s/he may feel its effects). This apparent paradox is, in fact, a fundamental characteristic of hegemony, which "excludes alternatives and rival forms of thought" and "obfuscates its impacts." ${ }^{58}$ It is precisely because neoliberalism is part of our everyday lives that it remains largely invisible to us. This might explain why LIS has paid little attention to neoliberalism to date..$^{59}$ 
In conclusion, I want to emphasize that I am not suggesting that customer service is not important, nor am I arguing that libraries need never adapt or change. As Budd states, "attention to... customer service model[s]... is both necessary and correct" because it reminds us of "the external purpose that drives the library: the teaching, learning, and research that is at the heart of the college or university." ${ }^{\prime 0}$ I agree with Seale's suggestion that

these ideas of better services, increased access, more choices, and greater freedom are powerful, and they strongly resonate with the core values of librarianship... it is undoubtedly due to this resonance that they have become a key part of the dominant discourse within librarianship. ${ }^{61}$

A colleague pointed out to me that the language of "education as skills for employability" resonates in a particular way at her institution where nearly half the population is made up of first-generation students for whom college is a "step up." Her students, like many others, want to be employable "knowledge workers" and see higher education as a means to achieve that end. Libraries play an important role in helping students to develop critical thinking and information literacy skills, she added. For me, what is at issue is the normative, instrumentalist view that the sole purpose of a college or university education is to develop skills for the job market. (I also question the dominant view that information literacy is a set of cognitive, decontextualized, and transferable skills, since research in New Literacy Studies-and more recently in LIS-suggests that literacy is an array of situated, contextualized practices but that discussion is beyond the scope of this essay. ${ }^{62}$ ) My colleague and I agree, however, that we need to find productive ways to talk about our role in preparing students for work while continuing to advocate for education and libraries as public goods. We need to frame our critiques of neoliberalism in higher education in a manner that acknowledges the socioeconomic and political realities of our campuses and lobbies for change at the same time. The point I'm making, one that others have made before me, is that we need to acknowledge the neoliberal context - the McDonaldized paradigm - within which we practice to think critically about its impact and consider what constraints and affordances it presents. In the words of Elmborg, "being critical allows us to see that the institutions we create are constructed by us, and they represent the values we choose to encode in them." 63

A number of LIS scholars have proposed alternative paradigms for thinking about the purpose and value of libraries and library work. Budd calls for us to explore numerous possible ends and to consider the "informing quality" and intellectual value of information (and, I add, information work). ${ }^{64}$ He cautions librarians

to take care with the language they adopt, and with the facility with which they use it to shape concepts. That the language of consumerism and commodification dominates beyond the sphere of libraries is not sufficient reason to accept it uncritically. The library's language, and practice, should flow from as clear an idea of purpose as possible. And librarians should examine purpose independently from the pressures of capitalism and consumption. ${ }^{65}$

Fister suggests that, as a profession, we have confounded value with values, and urges us to consider why we do things instead of measuring what we do. ${ }^{66}$ Shana Higgins and Lua Gregory ask: "Is it possible to re-orient the conversation in order to re-value conceptions of value?"67 I join my voice to this growing chorus and suggest that, rather than focusing on designing better customer/user experiences through trans- 
formational change, a frame in which quality is defined as fitness for purpose or value for money, we should consider how our efforts contribute to making higher education a transformative experience, a frame in which quality is about value added. ${ }^{6}$ Personally, I find the following quote from Elmborg far more compelling, and far more inspiring, than calls to consider the library a "capacity-building enterprise," a "platform," or a "value proposition."

We can choose to become more like commercial entities with products and customer bases, or we can aim to be socially meaningful institutions with a higher role and calling. We can become bookstores in an effort to beat bookstores, or we can work to build libraries and librarianship around the concept of shared social space where real people engage in real struggle for meaning and purpose in a landscape of increasingly rapid human movement and social change. ${ }^{69}$

Ritzer speculates that the McDonaldization of society is inexorable. ${ }^{70}$ If Quinn's "The McDonaldization of Academic Libraries?" does indeed foreshadow the continued commodification of academic libraries and the dismantling of the public sphere, Ritzer may be correct. And while I don't claim to know one way or the other, one thing about which I am certain is that we have a choice whether to consume the message along with the food. ${ }^{71}$

\section{Notes}

1. Brian Quinn, "The McDonaldization of Academic Libraries?" College and Research Libraries 61, no. 3 (2000): 248-61; George Ritzer, The McDonaldization of Society: An Investigation into the Changing Character of Contemporary Social Life (Thousand Oaks, Calif.: Pine Forge Press, 1993).

2. Brian Quinn, "The McDonaldization of Academic Libraries?" College and Research Libraries 76, no. 3 (2015): 345.

3. Quinn, "The McDonaldization of Academic Libraries?" (2015): 339, 345.

4. Quinn, "The McDonaldization of Academic Libraries?" (2015): 347. Gavin Poynter points out that the pace of innovation and diffusion in the "information age" is actually much slower that it was in other "industrial revolutions." Gavin Poynter, "Modules and Work: Education and Work in the 'Information Age,"' in The McDonaldization of Higher Education, eds. Dennis Hayes and Robin Wynyard (Westport, Conn.: Greenwood Press, 2002), 59.

5. Carla J. Stoffle, Robert Renaud, and Jerilyn R. Veldof, "Choosing Our Futures," College $\mathcal{E}$ Research Libraries 57, no. 3 (May 1, 1996): 213-25, doi:10.5860/crl_57_03_213; Donald E. Riggs, "What's in Store for Academic Libraries? Leadership and Management Issues," Journal of Academic Librarianship 23, no. 1 (1997): 3-8; James G. Neal, "The Entrepreneurial Imperative Advancing from Incremental to Radical Change in the Academic Library," portal: Libraries and the Academy 1, no. 1 (2001): 1-13, doi:10.1353/pla.2001.0006; Denise A. Troll, "How and Why Libraries Are Changing: What We Know and What We Need to Know," portal: Libraries and the Academy 2, no. 1 (2002): 99-123.

6. Stoffle, Renaud, and Veldof, "Choosing Our Futures," 220.

7. Stoffle, Renaud, and Veldof, "Choosing Our Futures," 223.

8. Neal, "The Entrepreneurial Imperative," 1.

9. See John Buschman, "Myths of the Information Society: A Guide for Librarians," Urban Academic Librarian 9 (1994): 4-17; John M. Budd, "A Critique of Customer and Commodity," College \& Research Libraries 58, no. 4 (1997): 309-20; Mark Tyler Day, "Transformational Discourse: Ideologies of Organizational Change in the Academic Library and Information Science Literature," Library Trends 46, no. 4 (Spring 1998): 635-67. For "an analytical overview on how librarians saw and attempted to shape the future of their field during a period of unprecedented change," see also Ron Gilmour and Gregg Sapp, "A Brief History of the Future of Academic Libraries: Predictions and Speculations from the Literature of the Profession, 1975 to 2000-Part Two, 1990 to 2000," portal: Libraries and the Academy 3, no. 1 (2003): 13-34, doi:10.1353/pla.2003.0008.

10. Day, "Transformational Discourse," 655.

11. Day, "Transformational Discourse," 651.

12. James Gee, Glynda Hull, and Colin Lankshear, The New Work Order: Behind the Language 
of the New Capitalism (Boulder, Colo.: Westview Press, 1996).

13. Gee, Hull, and Lankshear, The New Work Order, 27.

14. Gee, Hull, and Lankshear, The New Work Order; Stephen Taylor, Sheena Smith, and Phil Lyon, "McDonaldization and Consumer Choice in the Future: An Illusion or the Next Marketing Revolution?" in McDonaldization Revisited: Critical Essays on Consumer Culture, eds. Mark Alfino, John S. Caputo, and Robin Wynyard (Westport, Conn.: Praeger, 1998), 105-20.

15. Ritzer, The McDonaldization of Society, 25-27; Taylor, Smith, and Lyon, "McDonaldization and Consumer Choice in the Future," 108-09.

16. Gee, Hull, and Lankshear, The New Work Order, 35.

17. Gee, Hull, and Lankshear, The New Work Order, 19.

18. American Library Association, "Emerging Leaders," available online at www.ala.org/ educationcareers/leadership/emergingleaders [accessed 16 December 2014].

19. Gee, Hull, and Lankshear, The New Work Order, 6.

20. Gee, Hull, and Lankshear, The New Work Order, 44.

21. Quinn, "The McDonaldization of Academic Libraries?" (2015): 345.

22. Mark Olssen and Michael A. Peters, "Neoliberalism, Higher Education and the Knowledge Economy: From the Free Market to Knowledge Capitalism," Journal of Education Policy 20, no. 3 (Jan. 2, 2005): 313-45, doi:10.1080/02680930500108718; Susan Robertson, "Challenges Facing Universities in a Globalising World" (paper presented at the International Seminar on Quality in Higher Education: Indicators and Challenges, Pontifical Catholic University of Rio Grande do Sul, Brazil, 2010), available online at http://susanleerobertson.files.wordpress.com/2012/07/2010robertson-challenges.pdf [accessed 10 November 2014].

23. Michèle Charbonneau, "New Public Management," in Encyclopedic Dictionary of Public Administration, eds. Louis Côté and Jean-François Savard (2012), 2, available online at www. dictionnaire.enap.ca/dictionnaire/docs/definitions/definitions_anglais/new_management.pdf [accessed 16 December 2014].

24. Ritzer and several others use the term "McUniversity" in The McDonaldization of Higher Education, eds. Dennis Hayes and Robin Wynyard (Westport, Conn.: Greenwood Press, 2002).

25. Skills Development in Higher Education and Employment, eds. Neville Bennett, Elisabeth Dunne, and Clive Carré (Philadelphia, Pa.: Society for Research into Higher Education \& Open University Press, 2000); Organisation for Economic Cooperation and Development, Centre for Educational Research and Innovation, Competencies for the Knowledge Economy (Paris: OECD, 2001), available online at http://www.oecd.org/innovation/research/1842070.pdf [accessed 16 December 2014]; Marnie Holborow, "Neoliberalism, Human Capital and the Skills Agenda in Higher Education - the Irish Case," Journal for Critical Education Policy Studies 10, no. 1 (2007): 93-111; Brian Miller, "Skills for Sale: What Is Being Commodified in Higher Education?" Journal of Further and Higher Education 34, no. 2 (2010): 199-206; James Côté and Anton L. Allahar, Lowering Higher Education: The Rise of Corporate Universities and the Fall of Liberal Education (University of Toronto Press, 2011); Nathaniel F. Enright, "The Violence of Information Literacy: Neoliberalism and the Human as Capital," in Information Literacy and Social Justice, eds. Lua Gregory and Shana Higgins (Sacramento, Calif.: Library Juice Press, 2013), 15-38.

26. In the United States, more than 75 percent of faculty members are adjuncts and more than half of these live below the poverty line. In Canada, the majority of undergraduate students are currently taught by contract faculty. John W. Curtis, American Association of University Professors, The Employment Status of Instructional Staff Members, Fall 2011 (Washington, D.C.: The Association, Apr. 2014), available online at www.aaup.org/sites/default/files/files/AAUP-InstrStaff2011-April2014. pdf [accessed 16 December 2014]; House Committee on Education and the Work Force Democratic Staff, United States House of Representatives, The Just-in-Time Professor: A Staff Report Summarizing Eforum Responses on the Working Conditions of Contingent Faculty in Higher Education (Washington, D.C.: GPO, Jan. 2014), available online at http://democrats.edworkforce.house.gov/sites/ democrats.edworkforce.house.gov/files/documents/1.24.14-AdjunctEforumReport.pdf [accessed 25 October 2014]; Ira Basen, "Class Struggle," The Sunday Edition, Sept. 7, 2014, available online at http://podcast.cbc.ca/mp3/podcasts/sundayedition_20140905_48648.mp3 [accessed 25 October 2014]; Sharon Riley, "New Florida University Unveils Bookless Library," Library Journal, Aug. 18, 2014, http://lj.libraryjournal.com/2014/08/academic-libraries/new-florida-polytechnic-unveilsbookless-library/ [accessed 25 October 2014].

27. Olssen and Peters, "Neoliberalism, Higher Education and the Knowledge Economy," 328.

28. Liz Reisberg, "The Alarming Expansion of the For-Profits," The World View (blog), Inside Higher Ed, Oct. 27, 2014, available online at https:/www.insidehighered.com/blogs/world-view/ alarming-expansion-profits [accessed 16 December 2014]; Neal, "The Entrepreneurial Imperative," 5; Eden Dahlstrom, D. Christopher Brooks, and Jacqueline Bischel, The Current Ecosystem of Learning Management Systems in Higher Education: Student, Faculty, and IT Perspectives (research report) (Louisville, Colo.: ECAR, 2014). 
29. Association of College and Research Libraries, The Value of Academic Libraries, available online at www.acrl.ala.org/value/ [accessed 18 December 2014].

30. Barbara Fister, "Librarians as Agents of Change" (keynote address, Libraries Out Loud: New Narratives of Enduring Values, ACRL Oregon-Washington Joint Fall Conference, Corbett, Ore., 2012), 6, available online at http://homepages.gac.edu/ fister/ACRLORWA.pdf [accessed 18 December 2014].

31. In the 2012 edition of The McDonaldization of Society, Ritzer considers whether "Starbuckization" represents an alternative to, or replacement for, McDonaldization and concludes that it is neither. George Ritzer, The McDonaldization of Society: 20th Anniversary Edition (Thousand Oaks, Calif.: Sage, 2013), 71-77.

32. Cathy Eisenhower and Dolce Smith, "The Library as Stuck Place: Critical Pedagogy in the Corporate University," in Critical Library Instruction: Theories and Methods, eds. Maria Accardi, Emily Drabinski, and Ilana Kumbier (Sacramento, Calif.: Library Juice Press, 2010), 314.

33. In his critique of the McDonaldization of British higher education, Frank Furedi refers to "the ascendancy of the handout culture" in which "knowledge has become rationalized and turned into easily digestible products." Furedi, "The Bureaucratizaton of the British University," in The McDonaldization of Higher Education, eds. Hayes and Wynyard, 40. For Poynter, it represents "the triumph of process over content." Poynter also notes that the division of degree courses into credit-bearing modules (under the Bologna Process, for example) causes increasing predictability in teaching, learning, and assessment. Poynter, "Modules and Work," 59.

34. For a critique of best practices in higher education, see Peter Hlebowitsh, "When Best Practices Aren't: A Schwabian Perspective on Teaching," Journal of Curriculum Studies 44, no. 1 (Feb. 1, 2012): 1-12.

35. Seale demonstrates how dominant conceptions and practices of IL, such as those advocated in standards and best practice guidelines, continue to "reproduce themselves and act to constrain alternative discourses that might critique, contest, and challenge their hegemony; they deploy power and define the truth of teaching and learning within librarianship." Maura Seale, "The Neoliberal Library," in Information Literacy and Social Justice: Radical Professional Praxis, eds. G. Lua and S. Higgins (Sacramento, Calif.: Library Juice Press, 2013), 39-61.

36. Maura Seale, "Marketing Information Literacy," Communications in Information Literacy 7 , no. 2 (2013): 155, emphasis added.

37. Neal, "The Entrepreneurial Imperative," 10; Penni Stewart, "Academic Librarians Are under Attack," CAUT/ ACPPU Bulletin 56, no. 10 (2009), available online at https://www.cautbulletin. ca/en_article.asp?articleid=2958 [accessed 25 October 2014].

38. For a discussion and critique of rational choice theory, see Donald P. Green and Ian Shapiro, Pathologies of Rational Choice Theory: A Critique of Applications in Political Science (New Haven, Conn.: Yale University Press, 1996).

39. Budd, "A Critique of Customer and Commodity," 314.

40. Barbara Fister, "Disruption and the Value of Small Things," Library Babel Fish (blog), Inside Higher Ed, June 18, 2014, available online at https://www.insidehighered.com/blogs/library-babelfish/disruption-and-value-small-things [accessed 10 November 2014].

41. John Buschman, "Libraries and the Decline of Public Purposes," Public Library Quarterly 24, no. 1 (2005): 1-12; Fister, "Librarians as Agents of Change."

42. Ritzer, The McDonaldization of Society, 19.

43. John S. Caputo, "The Rhetoric of McDonaldization," in McDonaldization Revisited: Critical Essays on Consumer Culture, eds. Mark Alfino, John S. Caputo, and Robin Wynyard (Westport, Conn.: Praeger, 1998): 39-52; Mark Alfino, "Postmodern Hamburgers: Taking a Postmodern Attitude Towards McDonalds," in McDonaldization Revisited," 175-89; Barry Smart, "Accounting for Anxiety: Economic and Cultural Imperatives Transforming University Life," in McDonaldization of Higher Education, 47-48.

44. Olssen and Peters, "Neoliberalism, Higher Education and the Knowledge Economy," 324.

45. John Buschman, Dismantling the Public Sphere: Situating and Sustaining Librarianship in the Age of the New Public Philosophy (Westport, Conn.: Libraries Unlimited, 2003).

46. Budd, "A Critique of Customer and Commodity," 312.

47. James K. Elmborg, "Libraries as the Spaces between Us: Recognizing and Valuing the Third Space," Reference \& User Services Quarterly 50, no. 4 (Summer 2011): 338-50.

48. Buschman, "Libraries and the Decline of Public Purposes," 6.

49. See Lee Harvey and Peter T. Knight, Transforming Higher Education (Buckingham, UK: Society for Research in Higher Education \& Open University Press, 1993); Budd, "A Critique of Customer and Commodity"; The McDonaldization of Higher Education, eds. Hayes and Wynyard; Henry A. Giroux, "Neoliberalism, Corporate Culture, and the Promise of Higher Education: The University as a Democratic Public Sphere," Harvard Educational Review 72 (2002): 425-63; Buschman, Dismantling the Public Sphere; Henry A. Giroux, Education and the Crisis of Public Values: 
Challenging the Assault on Teachers, Students, \& Public Education, vol. 400, Counterpoints (New York: Peter Lang, 2011).

50. Ronald Barnett, Realising the University in an Age of Supercomplexity (Ballmoor, UK: Open University Press, 2000), cited in Olssen and Peters, "Neoliberalism, Higher Education and the Knowledge Economy," 316; Robin Usher and Richard Edwards, Lifelong Learning: Signs, Discourses, Practices (Dordrecht, NL: Springer-Verlag, 2007).

51. Ritzer, The McDonaldization of Society, xii, emphasis added.

52. Ngure wa Machofi, "Missing the Cultural Basis of Irrationality in the McDonaldization Thesis," in McDonaldization Revisited: Critical Essays on Consumer Culture, eds. Alfino, Caputo, and Wynyard, 155.

53. John M. Budd, "Instances of Ideology In Discursive Practice: Implications for Library and Information Science," Library Quarterly 71, no. 4 (Oct. 2001): 515. According to Budd, the shared constructions of the communicative act, including context, grammar, and vocabulary, can be used to mask the writer's intentions and induce the interlocutor to accept the communication as persuasive or neutral. Bill Cope and Mary Kalantzis note that, because the new public management theory uses words familiar to educators, such as knowledge (as in "knowledge worker"), learning (as in "learning organization"), collaboration, alternative assessments, communities of practice, networks and others, we are more accepting of it. Multiliteracies: Literacy Learning and the Design of Social Futures, eds. Bill Cope and Mary Kalantzis (London; New York: Routledge, 2000), 11.

54. Budd, "A Critique of Customer and Commodity"; Buschman, "Libraries and the Decline of Public Purposes"; Fister, "Librarians as Agents of Change."

55. David Harvey, A Brief History of Neoliberalism (Oxford University Press, 2005).

56. For examples, see Brian Mathews, Think like a Startup: A White Paper to Inspire Library Entrepreneurialism, Working Paper (Apr. 3, 2012), available online at http://vtechworks.lib.vt.edu/ handle/10919/18649 [accessed 28 November 2014]; and Stephen J. Bell, Designing Better Libraries (blog), available online at http://dbl.lishost.org/blog/\#.VHidrKTF_dc [accessed 3 October 2014] and From the Bell Tower (blog), Library Journal, available online at http://lj.libraryjournal.com/ category/opinion/steven-bell/ [accessed 3 October 2014].

57. Daniel B. Saunders, "Neoliberal Ideology and Public Higher Education in the United States," Journal for Critical Education Policy Studies 8, no. 1 (2010).

58. Saunders, "Neoliberal Ideology and Public Higher Education," 49.

59. Enright, "The Violence of Information Literacy."

60. Budd, "A Critique of Customer and Commodity," 309.

61. Seale, "The Neoliberal Library," 56.

62. See Brian Street, Literacy in Theory and Practice (Cambridge University Press, 1984); Allan Luke and Cushla Kapitzke, "Literacies and Libraries: Archives and Cybraries," Pedagogy, Culture E Society 7, no. 3 (Jan. 11, 1999): 467-91, doi:10.1080/14681369900200066; Situated Literacies: Reading and Writing in Context, eds. David Barton, Mary Hamilton, and Roz Ivanic (London; New York: Routledge, 2000); Multiliteracies: Literacy Learning and the Design of Social Futures, eds. Bill Cope and Mary Kalantzis (New York: Routledge, 2000); Kimmoa Tuominen, Reijo Savolainen, and Sanna Talja, "Information Literacy as a Sociotechnical Practice," Library Quarterly 75, no. 3 (Jan. 7, 2005): 329-45, doi:10.1086/497311; Annemaree Lloyd, "Framing Information Literacy as Information Practice: Site Ontology and Practice Theory," Journal of Documentation 66, no. 2 (2010): 245-58, doi:10.1108/00220411011023643; “Trapped between a Rock and a Hard Place: What Counts as Information Literacy in the Workplace and How Is It Conceptualized?" Library Trends 60, no. 2 (2011): 277-96, doi:10.1353/lib.2011.004; "Information Literacy as a Socially Enacted Practice," Journal of Documentation 68, no. 6 (2012): 772-83, doi:10.1108/00220411211277037.

63. James K. Elmborg, "Framing a Vision for 21st-Century Librarianship: LIS Education in Changing Times," Serials Librarian 55, no. 4 (2008): 506.

64. Budd, "A Critique of Customer and Commodity," 316.

65. Budd, "Instances of Ideology in Discursive Practice."

66. Fister, "The Self-Centered Library: A Paradox," Library Babel Fish (blog), Inside Higher Ed, Aug. 28, 2012, available online at https://www.insidehighered.com/blogs/library-babel-fish/selfcentered-library-paradox [accessed 10 November 2014].

67. Lua Gregory and Shana Higgins, "Academic Libraries, Information Literacy, and the Value of Our Values," Library Juice: On the Intersection of Libraries, Politics, and Culture (blog), Nov. 8, 2012, available online at http://libraryjuicepress.com/blog/?p=3706 [accessed 10 November 2014].

68. Lee Harvey and Peter T. Knight identify the following five meanings attributed to "quality" in the higher education literature on quality assurance: 1) quality as exceptional, evidenced in exceptionally high standards of academic achievement or ranking tables; 2 ) quality as perfection (or consistency), which focuses on processes and their specifications and is related to zero defects and quality culture; 3) quality as fitness for purpose, which judges the quality of a product or service in 
terms of the extent to which its stated purpose-defined either as meeting customer specifications or conformity with the institutional mission-is met; 4) quality as value for money, which assesses quality in terms of return on investment or expenditure and is related to accountability; and 5) quality as transformation or value-added, in which quality is viewed as a process of qualitative change with emphasis on empowering students. They underscore that the first four represent possible operationalizations of the transformative process rather than ends in themselves. In my view, this suggests once again that we have conflated means with ends. Harvey and Knight, Transforming Higher Education, 15-16.

69. Elmborg, "Libraries as the Spaces between Us," 349.

70. Ritzer, The McDonaldization of Society, 8-9.

71. Both Caputo and Alfino make the point that, as a form of consumption, dining at McDonald's is more about buying into the message than it is about eating the food. Caputo, "The Rhetoric of McDonaldization," 49; Alfino, "Postmodern Hamburgers," 182. 